\title{
Effect of $\beta$-cyclodextrin on the extraction of isoxazolines from aqueous ethanol into chloroform
}

\author{
Christopher J. Easton,, ${ }^{\text {a, }}$ C. Merrîcc Hughes, ${ }^{\text {b }}$ Stephen F. Lincoln, ${ }^{\text {b Gregory W. Simpson, }}$ \\ and George J. Vuckovic ${ }^{\mathrm{a}}$ \\ ${ }^{a}$ Research School of Chemistry, Institute of Advanced Studies, Australian National University, \\ Canberra ACT 0200, Australia ${ }^{b}$ Department of Chemistry, University of Adelaide, Adelaide SA \\ 5005, Australia ${ }^{c}$ CSIRO Molecular Science, Bayview Ave, Clayton Vic 3168, Australia \\ E-mail:easton@rsc.anu.edu.au
}

\section{Dedicated to Oswald S. Tee on the occasion of his $60^{\text {th }}$ birthday, and in recognition of his many contributions to chemistry \\ (received 01 Sep 01; accepted 22 Oct 01; published on the web 30 Oct 01)}

\begin{abstract}
Regioisomeric pairs of isoxazolines were prepared through reaction of nitrile oxides with ethyl trans-cinnamate. The effect of $\beta$-cyclodextrin on the solubility of these compounds in aqueous ethanol and their extraction into chloroform has been examined. Somewhat anomalously, the compound which is least soluble in the aqueous ethanol is least efficiently extracted into the chloroform, presumably because it is most extensively complexed by the cyclodextrin. In one case, extraction of a 1:1 mixture of a regioisomeric pair of isoxazolines resulted in the separation of ca. $50 \%$ of each of the compounds in ca. $90 \%$ purity, from a single partitioning.
\end{abstract}

Keywords: Isoxazolines, extraction, $\beta$-cyclodextrin, nitrile oxides, ethyl trans-cinnmate

\section{Introduction}

In a series of articles published in the early 1990s, Rama Rao et al. ${ }^{1}$ reported that baker's yeast catalysed 1,3-dipolar cycloaddition reactions of nitrile oxides with cinnamates, vinylpyridines, acrylates and vinylcarbazoles, and that $\beta$-cyclodextrin affected the regioselectivity and stereoselectivity of some of these processes. Our preliminary investigations in this area ${ }^{2}$ showed that neither yeast nor $\beta$-cyclodextrin significantly affected the cycloadditions, but $\beta$-cyclodextrin did have some effect on the isolation of the cycloadducts from the product mixtures. The effects could be duplicated in simple extraction procedures. Accordingly, when a 1:1 mixture of the isoxazolines $\mathbf{6 a}$ and $\mathbf{7 a}$, or $\mathbf{6 b}$ and $\mathbf{7 b}$, in ethanol-water $(1: 4, \mathrm{v} / \mathrm{v})$ containing $\beta$-cyclodextrin $(0.05$ mol $\mathrm{dm}^{-3}$ ) was extracted with organic solvents, samples enriched in either $\mathbf{6 a}$ or $\mathbf{6 b}$ were 
obtained. No enrichment was observed in the absence of a cyclodextrin. To examine these effects in more detail, we have now included the isoxazolines $\mathbf{6 c , d}$ and 7c,d in our studies. These were chosen because compounds containing the tert-butylphenyl moiety are known to form very stable cyclodextrin inclusion complexes, while a tert-butyl group associates with $\beta$-cyclodextrin only weakly. ${ }^{3,4}$ We have studied the effect of $\beta$-cyclodextrin on the extraction of the isoxazolines 6a-d and 7a-d from aqueous ethanol into chloroform, and correlated the trends seen in these experiments with the solubility of the isoxazolines $\mathbf{6 a - d}$ and $7 \mathbf{a}-\mathbf{d}$ in aqueous ethanol, in the presence and absence of the cyclodextrin.

\section{Results and Discussion}

The isoxazolines $\mathbf{6 a - d}$ and $\mathbf{7 a - d}$ were prepared as shown in Scheme 1. ${ }^{5}$ The aldehydes 1a-d were treated with hydroxylamine to give the corresponding oximes $\mathbf{2 a - d}$, which reacted with $N$ chlorosuccinimide to give the hydroximinoyl chlorides 3a-d, respectively. The nitrile oxides 4ad were prepared in situ from the corresponding hydroximinoyl chlorides 3a-d, through treatment with triethylamine, and they reacted with ethyl trans-cinnamate $\mathbf{5}$ to give the cycloadducts $\mathbf{6 a - d}$ and 7a-d, respectively, which were separated using flash column chromatography.
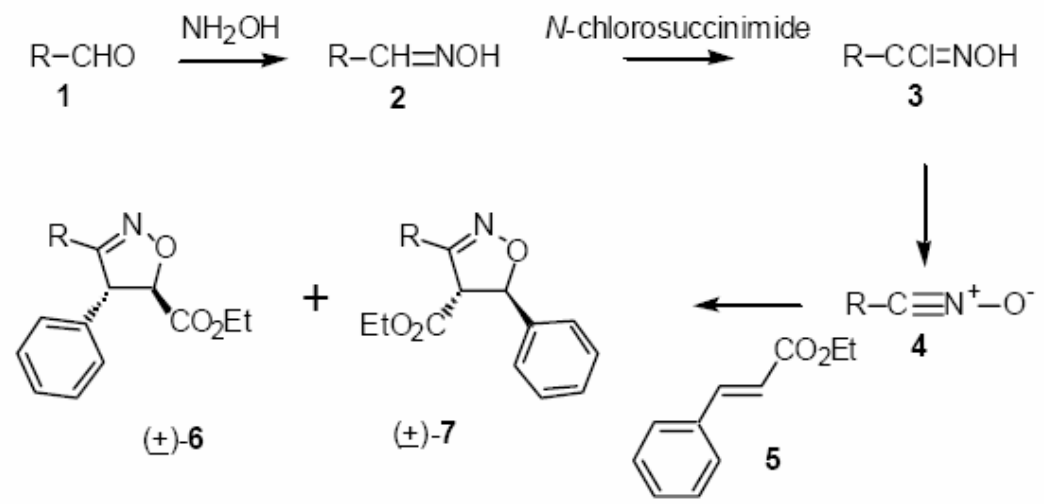

\section{Scheme 1}
a) $R=2,6$-dichlorophenyl
b) $\mathrm{R}=2,4,6$-trimethylphenyl
c) $R=4$-tert-butylphenyl
d) $\mathrm{R}=$ tert-butyl

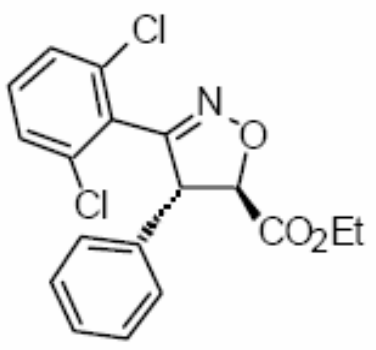

$\stackrel{(+)-6 a}{a}$<smiles>CCOC(=O)[C@H]1C(c2c(Cl)cccc2Cl)=NO[C@H]1c1ccccc1</smiles>

$( \pm)-7 a$ 


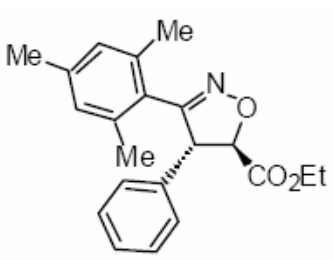

$( \pm)-6 b$

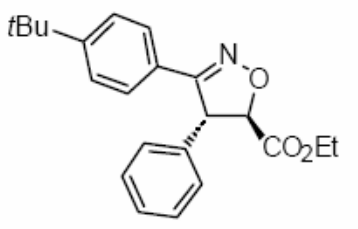

$( \pm)-6 c$

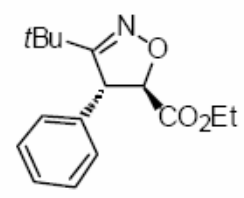

$( \pm)-6 \mathrm{~d}$

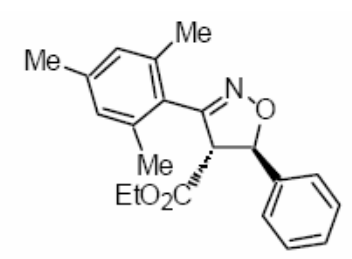

$(+)-7 \mathrm{~b}$

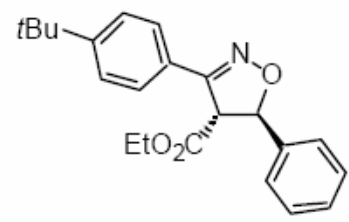

$( \pm)-7 \mathrm{c}$

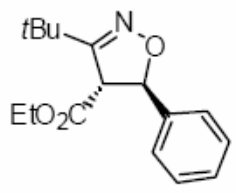

$(+)-7 d$

The regioisomers $\mathbf{6 a - d}$ and $\mathbf{7 a - d}$ were distinguished on the basis of their ${ }^{1} \mathrm{H}$ NMR spectra. As reported previously for similar compounds, ${ }^{6}$ the resonances for the C-4 and C-5 protons of the 5-ethoxycarbonyl-4-phenylisoxazolines 6a-d are closer in chemical shift $(\Delta \delta<0.5 \mathrm{ppm})$ and show smaller coupling constants $(J<5.5 \mathrm{~Hz})$ than those observed for the corresponding 4ethoxycarbonyl-5-phenylisoxazolines $7 \mathbf{a}-\mathbf{d}(\Delta \delta>1.5 \mathrm{ppm}, J>6.0 \mathrm{~Hz})$. The structure of the isoxazoline 7a was confirmed through X-ray crystallographic analysis. ${ }^{7}$ Polar effects generally dominate the regioselectivity in reactions of nitrile oxides with 1,2-disubstituted dipolarophiles ${ }^{5}$ and, as expected on this basis, the 4-ethoxycarbonyl-5-phenylisoxazolines 7a, 7c and 7d formed in preference to their regioisomers $\mathbf{6 a}, \mathbf{6 c}$ and $\mathbf{6 d}$, through selective reaction of the electron-rich oxygen of the nitrile oxides $\mathbf{4 a}, \mathbf{4 c}$ and $\mathbf{4 d}$ at the electron-deficient carbon of the dipolarophile 5. By contrast, the isoxazolines $\mathbf{6 b}$ and $\mathbf{7 b}$ formed in approximately equal quantities, presumably as a result of the steric bulk of the mesityl group of the nitrile oxide $4 b$, increasing the tendency of the oxygen of the dipole $\mathbf{4 b}$ to add to the least hindered carbon of the dipolarophile $5^{5}$

Solutions of the regioisomeric pairs of the isoxazolines $\mathbf{6 a - d}$ and $7 \mathbf{a}-\mathbf{d}$ in ethanol/water (1:4, $\mathrm{v} / \mathrm{v})$ containing $\beta$-cyclodextrin $\left(0.05 \mathrm{~mol} \mathrm{dm}^{-3}\right)$ were extracted with chloroform, and the results are shown in Table 1. The isoxazolines $\mathbf{6 d}$ and $\mathbf{7 d}$ were extracted effectively and without selectivity. By comparison, with the isoxazolines $\mathbf{6 a} \mathbf{a}, \mathbf{b}$ and $\mathbf{7 a}, \mathbf{b}$, a modest selectivity for phase transfer of $\mathbf{6 a}$ over $\mathbf{7 a}$, and of $\mathbf{6 b}$ over $\mathbf{7 b}$ was observed, while the experiments with $\mathbf{6 c}$ and $\mathbf{7 c}$ showed a more substantial selectivity and the phase transfer of 7c was significantly retarded. In practical terms it was possible to obtain approximately $50 \%$ of each of the isoxazolines $6 \mathbf{c}$ and $7 \mathrm{c}$ in approximately $90 \%$ purity, from a single partitioning of a 1:1 mixture. 
Table 1. Percentage recovery of the isoxazolines $\mathbf{6 a - d}$ and $7 \mathbf{a}-\mathbf{d}$ following extraction into chloroform from ethanol/water $(1: 4, \mathrm{v} / \mathrm{v})$ solutions containing $\beta$-cyclodextrin $\left(0.05 \mathrm{~mol} \mathrm{dm}^{-3}\right)$ and equimolar mixtures of pairs of the regioisomers $\left(0.005 \mathrm{~mol} \mathrm{dm}^{-3}\right)$

\begin{tabular}{ccccc}
\hline Isoxazoline & \multicolumn{4}{c}{ Number of extractions } \\
\hline & $\mathbf{1}$ & $\mathbf{2}$ & $\mathbf{3}$ & $\mathbf{4}$ \\
$\mathbf{6 a}$ & 60 & 85 & $>95$ & \\
$\mathbf{7 a}$ & 45 & 80 & $>95$ & \\
$\mathbf{6 b}$ & 85 & $>95$ & & \\
$\mathbf{7 b}$ & 40 & 80 & $>95$ & \\
$\mathbf{6 c}$ & 45 & 80 & 95 & $>95$ \\
$\mathbf{7 c}$ & 5 & 20 & 40 & $55^{*}$ \\
$\mathbf{6 d}$ & 75 & 95 & $>95$ & \\
$\mathbf{7 d}$ & 75 & 95 & $>95$ & \\
\hline
\end{tabular}

* $>95 \%$ recovered through further extraction with ethyl acetate

To explore the origin of these effects, the solubility of the isoxazolines $\mathbf{6 a}-\mathbf{d}$ and $7 \mathbf{a}-\mathbf{d}$ in ethanol/water $(1: 4, \mathrm{v} / \mathrm{v})$ was measured, in the presence and absence of $\beta$-cyclodextrin $(0.05 \mathrm{~mol}$ $\mathrm{dm}^{-3}$ ), and the results are shown in Table 2 . At this concentration $\beta$-cyclodextrin either increased or had no effect on the solubility of each of the isoxazolines $6 \mathbf{a}, \mathbf{6 c}, \mathbf{6 d}$ and $\mathbf{7 a - d}$ in the aqueous ethanol, while lower concentrations of $\beta$-cyclodextrin resulted in similar but proportionately reduced effects. When $\beta$-cyclodextrin was added to a solution of the isoxazoline $\mathbf{6 b}$, the concentration of the isoxazoline $\mathbf{6 b}$ decreased, presumably due to precipitation of the $\beta$ cyclodextrin-isoxazoline $\mathbf{6 b}$ complex. Consequently it was not practical to quantify the effect of $\beta$-cyclodextrin on the solubility of the isoxazoline $\mathbf{6 b}$.

Table 2. Solubility of the isoxazolines $6 \mathbf{a}-\mathbf{d}$ and $\mathbf{7 a}-\mathbf{d}$ in ethanol/water $(1: 4, \mathrm{v} / \mathrm{v})$ at $30^{\circ} \mathrm{C}$, in the presence and absence of $\beta$-cyclodextrin $\left(0.05 \mathrm{~mol} \mathrm{dm}^{-3}\right)$

\begin{tabular}{ccc}
\hline Isoxazoline & \multicolumn{2}{c}{ Solubility $\left(\mathrm{mol} \mathrm{dm}^{-3}\right)$} \\
\hline & No cyclodextrin & With $\beta$-cyclodextrin \\
$\mathbf{6 a}$ & $1.8 \times 10^{-5}$ & $1.8 \times 10^{-5}$ \\
$\mathbf{7 a}$ & $1.1 \times 10^{-5}$ & $1.0 \times 10^{-4}$ \\
$\mathbf{6 b}$ & $1.7 \times 10^{-5}$ & $-*$ \\
$\mathbf{7 b}$ & $2.8 \times 10^{-6}$ & $5.2 \times 10^{-5}$ \\
$\mathbf{6 c}$ & $4.9 \times 10^{-6}$ & $1.0 \times 10^{-4}$ \\
$\mathbf{7 c}$ & $9.4 \times 10^{-9}$ & $1.1 \times 10^{-5}$ \\
$\mathbf{6 d}$ & $2.5 \times 10^{-4}$ & $1.7 \times 10^{-3}$ \\
$\mathbf{7 d}$ & $6.7 \times 10^{-4}$ & $4.1 \times 10^{-3}$ \\
\hline
\end{tabular}

*Not determined - see text for explanation 
The results shown in Tables 1 and 2 are anomalous in that the isoxazoline 7c which is the least soluble in the aqueous ethanol is least effectively extracted into chloroform, while compounds 6d and 7d which are the most soluble in the aqueous ethanol are among those which most readily transfer. Presumably the cause of this anomaly is the cyclodextrin. The effect of the cyclodextrin on the solubility of the isoxazolines $\mathbf{6 a}, \mathbf{6 c}, \mathbf{6 d}$ and $7 \mathbf{a}-\mathbf{d}$ indicates the extent to which they are complexed by the cyclodextrin. The data in Table 2 show that of the isoxazolines 6c and 7c, the latter is much less soluble in the aqueous ethanol and much more extensively complexed by the cyclodextrin. Consequently, at any time there will be less present uncomplexed in solution and available for extraction into chloroform. It appears that the complexed isoxazolines are not extracted and that dissociation of the isoxazolines from the cyclodextrin complexes is sufficiently slow to retard the extraction process. The selectivity of phase transfer is less with the dichlorophenylisoxazolines $\mathbf{6 a}$ and $\mathbf{7 a}$, and negligible with the tertbutylisoxazolines $\mathbf{6 d}$ and $\mathbf{7 d}$, decreasing as the solubility in the aqueous ethanol increases and the tendency to be complexed by the cyclodextrin decreases. The partitioning of the isoxazolines $\mathbf{6 b}$ and $\mathbf{7 b}$ is a particular case, where it seems likely that chloroform dissolves the isoxazoline $\mathbf{6 b}$ from the precipitated cyclodextrin-isoxazoline $\mathbf{6 b}$ complex.

\section{Experimental Section}

General Procedures. Melting points were determined on a Kofler hot-stage apparatus under a Reichert microscope and are uncorrected. ${ }^{1} \mathrm{H}$ NMR spectra were recorded on either a Bruker ACP-300, a Varian Gemini 300 or a Varian Mercury 300 spectrometer, as dilute solutions in $\mathrm{CDCl}_{3}$. Electron impact mass spectra were recorded on either a VG Micromass $7070 \mathrm{~F}$ or an AEI MS-30 spectrometer, operating at an ionisation potential of $70 \mathrm{eV}$. Elemental analyses were performed by either the Microanalytical Laboratory, Research School of Chemistry, Australian National University, or Chemical and Microanalytical Services Pty. Ltd., Melbourne, Australia. Chromatography was performed using Merck-Keiselgel 60 (230-400 mesh ASTM). The aldehydes $1 \mathrm{a}-\mathrm{d}$ and ethyl trans-cinnamate 5 were purchased from Aldrich Chemical Co.

\section{General procedure for preparation of the oximes $2 a-d$ from the corresponding aldehydes} 1a-d

Hydroxylamine hydrochloride $(0.45 \mathrm{~g}, 6.5 \mathrm{mmol})$ was added to a solution of the aldehyde $(5.7 \mathrm{mmol})$ in water $(1.5 \mathrm{~mL})$, ethanol $(2 \mathrm{~mL})$ and ice $(2.5 \mathrm{~mL})$. Aqueous sodium hydroxide $(50 \%, 1.43 \mathrm{~mL})$ was then added and the mixture was stirred for $1.5 \mathrm{~h}$, then it was washed with ether $(1 \times 10 \mathrm{~mL})$, acidified (concd $\mathrm{HCl})$ and extracted with ether $(2 \times 10 \mathrm{~mL})$. The combined extracts were dried $\left(\mathrm{MgSO}_{4}\right)$ and concentrated under reduced pressure. The resulting solid was recrystallised from aqueous ethanol.

2,6-Dichlorobenzaldoxime (2a). Reaction of 2,6-dichlorobenzaldehyde 1a (1.00 g, $5.7 \mathrm{mmol})$ afforded the title compound $2 \mathbf{a}$ as small white needle-like crystals $(0.68 \mathrm{~g}, 63 \%)$; mp 148.8- 
$149.3{ }^{\circ} \mathrm{C} ;{ }^{1} \mathrm{H}$ NMR $\delta 7.2-7.4(3 \mathrm{H}, \mathrm{m}, \mathrm{Ar}-\mathrm{H}), 8.39$ (1H, bs, Ar-CH=NOH), 8.80 (1H, s, Ar$\mathrm{CH}=\mathrm{NOH})$. 2,4,6-Trimethylbenzaldoxime 2b. Reaction of 2,4,6-trimethylbenzaldehyde $\mathbf{1 b}$ $(2.00 \mathrm{~g}, 13.5 \mathrm{mmol})$ afforded the title compound $\mathbf{2 b}$ as small colorless trapezoid crystals $(0.61 \mathrm{~g}$, 28\%); mp 124-125 ${ }^{\circ} \mathrm{C}$ (lit. $\left.{ }^{8} 125-127{ }^{\circ} \mathrm{C}\right) ;{ }^{1} \mathrm{H}$ NMR $\delta 2.30\left(3 \mathrm{H}, \mathrm{s}, \mathrm{CH}_{3}\right), 2.39$ [6H, s, $\left.\left(\mathrm{CH}_{3}\right)_{2}\right]$, $6.90(2 \mathrm{H}, \mathrm{s}, \mathrm{Ar}-\mathrm{H}), 8.43(1 \mathrm{H}, \mathrm{s}, \mathrm{Ar}-\mathrm{CH}=\mathrm{NOH}), 8.90(1 \mathrm{H}, \mathrm{bs}, \mathrm{CH}=\mathrm{NOH})$.

4-tert-Butylbenzaldoxime (2c). Reaction of 4-tert-butylbenzaldehyde 1c (7.76 g, $47.8 \mathrm{mmol})$ afforded the title compound 2c as colorless needle-like crystals $(4.37 \mathrm{~g}, 52 \%)$; mp 104-106 ${ }^{\circ} \mathrm{C}$; ${ }^{1} \mathrm{H}$ NMR $\delta 1.32\left[9 \mathrm{H}, \mathrm{s},\left(\mathrm{CH}_{3}\right)_{3}\right], 7.40(2 \mathrm{H}, \mathrm{d}, J=6.5 \mathrm{~Hz}, \mathrm{Ar}-\mathrm{H}), 7.52(2 \mathrm{H}, \mathrm{d}, J=6.5 \mathrm{~Hz}, \mathrm{Ar}-\mathrm{H})$, $8.14(1 \mathrm{H}, \mathrm{bs}, \mathrm{CH}=\mathrm{NOH}), 8.48(1 \mathrm{H}, \mathrm{s}, \mathrm{Ar}-\mathrm{CH}=\mathrm{NOH})$.

Pivaldoxime (2d). Reaction of pivaldehyde 1d (2.00 g, $23.2 \mathrm{mmol})$ afforded the title compound 2d as a pale yellow oil (2.15 g, 92\%). ${ }^{1} \mathrm{H}$ NMR $\delta 1.11$ [9H, s, (CH3)3], $8.24(1 \mathrm{H}, \mathrm{bs}, \mathrm{CH}=\mathrm{NOH})$, $8.48(1 \mathrm{H}, \mathrm{s}, \mathrm{CH}=\mathrm{NOH})$.

General procedure for preparation of the hydroximinoyl chlorides 3a-d from the corresponding oximes $2 \mathrm{a}-\mathbf{d}$

$\mathrm{N}$-Chlorosuccinimide $(3.51 \mathrm{~g}, 26.3 \mathrm{mmol})$ was added to a stirred solution of the oxime (26.3 mmol) in $N, N$-dimethylformamide $(22 \mathrm{~mL})$. The reaction was initially slightly endothermic but soon became exothermic and was kept at $25-35^{\circ} \mathrm{C}$ in an ice bath. When the exothermic reaction ceased the solution was poured into ice/water $(100 \mathrm{~mL})$ and the mixture was extracted with ether $(2 \times 50 \mathrm{~mL})$. The combined extracts were washed with water $(3 \times 50 \mathrm{~mL})$, dried $\left(\mathrm{MgSO}_{4}\right)$ and concentrated under reduced pressure. The resulting solid was recrystallised from ether/n-hexane.

2,6-Dichlorobenzohydroximinoyl chloride (3a). Reaction of 2a (5.00 g, $26.3 \mathrm{mmol})$ afforded the title compound 3a as large rectangular colorless crystals $(4.60 \mathrm{~g}, 78 \%) ; \mathrm{mp} 89-91{ }^{\circ} \mathrm{C} ;{ }^{1} \mathrm{H}$ NMR $\delta$ 7.31-7.41 (3H, m, Ar-H), $8.41[1 \mathrm{H}, \mathrm{s}, \mathrm{Ar}-\mathrm{C}(\mathrm{Cl})=\mathrm{NOH}]$.

2,4,6-Trimethylbenzohydroximinoyl chloride (3b). Reaction of $\mathbf{2 b}(0.61 \mathrm{~g}, 3.73 \mathrm{mmol})$ afforded the title compound $\mathbf{3 b}$ as a pale yellow powder $(0.62 \mathrm{~g}, 84 \%) ; \mathrm{mp} 49-63{ }^{\circ} \mathrm{C} ;{ }^{1} \mathrm{H} \mathrm{NMR} \delta$ $2.28\left[6 \mathrm{H}, \mathrm{s},\left(\mathrm{CH}_{3}\right)_{2}\right], 2.41\left(3 \mathrm{H}, \mathrm{s}, \mathrm{CH}_{3}\right), 6.86(2 \mathrm{H}, \mathrm{s}, \mathrm{Ar}-\mathrm{H}), 8.31[1 \mathrm{H}, \mathrm{s}, \mathrm{C}(\mathrm{Cl})=\mathrm{NOH}]$.

4-tert-Butylbenzohydroximinoyl chloride (3c). Reaction of 2c (1.00 g, $5.6 \mathrm{mmol})$ afforded the title compound $3 \mathrm{c}$ as a pale yellow powder $(0.92 \mathrm{~g}, 77 \%)$; mp $69-73{ }^{\circ} \mathrm{C} ;{ }^{1} \mathrm{H} \mathrm{NMR} \delta 1.32[9 \mathrm{H}$, s, $\left.\left(\mathrm{CH}_{3}\right)_{3}\right], 7.43(2 \mathrm{H}, \mathrm{d}, J=6.5 \mathrm{~Hz}, \mathrm{Ar}-\mathrm{H}), 7.76(2 \mathrm{H}, \mathrm{d}, J=6.5 \mathrm{~Hz}, \mathrm{Ar}-\mathrm{H}), 8.49(1 \mathrm{H}, \mathrm{s}, \mathrm{Ar}-$ $\mathrm{CH}=\mathrm{NOH})$.

Pivalohydroximinoyl chloride (3d). Reaction of 2d (1.00 g, $9.9 \mathrm{mmol})$ afforded the title compound 3d as a pale yellow oil $(0.73 \mathrm{~g}, 54 \%) ;{ }^{1} \mathrm{H}$ NMR $\delta 1.25\left[9 \mathrm{H}, \mathrm{s},\left(\mathrm{CH}_{3}\right)_{3}\right], 8.44[1 \mathrm{H}, \mathrm{s}$, $\mathrm{C}(\mathrm{Cl})=\mathrm{NOH}]$.

General procedure for preparation of the isoxazolines $6 a-d$ and $7 a-d$ from the corresponding hydroximinoyl chlorides $3 a-d$ via the nitrile oxides $4 a-d$

A solution of triethylamine $(3.2 \mathrm{ml}, 21.5 \mathrm{mmol})$ and ethyl trans-cinnamate 5 (4.77 g, $27.1 \mathrm{mmol})$ in dry THF $(60 \mathrm{~mL})$ was added dropwise with stirring to the hydroximinoyl chloride 
$(16.3 \mathrm{mmol})$ in dry THF $(30 \mathrm{~mL})$. The mixture was stirred at room $\mathrm{T}$ for $1 \mathrm{~h}$, heated to reflux for a further $3 \mathrm{~h}$, then cooled and concentrated under reduced pressure. The residue was taken up in chloroform, and the solution was washed with water $(3 \times 50 \mathrm{~mL})$, dried $\left(\mathrm{MgSO}_{4}\right)$ and concentrated under reduced pressure. Analysis of the residue using ${ }^{1} \mathrm{H}$ NMR spectroscopy was carried out to determine the ratio of the two isoxazolines present in the product mixture. They were separated by flash chromatography on silica, eluting with ethyl acetate/n-hexane (1:5) and each was then recrystallised from ethyl acetate/ $n$-hexane.

trans-3-(2,6-Dichlorophenyl)-4,5-dihydro-4-phenyl-5-isoxazolecarboxylic acid ethyl ester 6a and trans-3-(2,6-dichlorophenyl)-4,5-dihydro-5-phenyl-4-isoxazolecarboxylic acid ethyl ester (7a). Reaction of 3a (3.67 g, $16.3 \mathrm{mmol})$ afforded a mixture of the title compounds $\mathbf{6 a}$ and 7a. in the ratio $15: 85$.

6a. $(0.48 \mathrm{~g}, 8 \%) ; \operatorname{mp~} 86-87{ }^{\circ} \mathrm{C} ;{ }^{1} \mathrm{H}$ NMR $\delta 1.34\left(3 \mathrm{H}, \mathrm{t}, J=7 \mathrm{~Hz}, \mathrm{CH}_{3}-\mathrm{CH}_{2}-\right), 4.32(2 \mathrm{H}, \mathrm{q}, J=7$ $\left.\mathrm{Hz}, \mathrm{CH}_{3}-\mathrm{CH}_{2}-\right), 5.24(1 \mathrm{H}, \mathrm{d}, J=5.5 \mathrm{~Hz}, \mathrm{C} 5-\mathrm{H}), 5.28(1 \mathrm{H}, \mathrm{d}, J=5.5 \mathrm{~Hz}, \mathrm{C} 4 \mathrm{H}), 7.22-7.46(8 \mathrm{H}$, m, Ar-H); Anal. Calcd for $\mathrm{C}_{18} \mathrm{H}_{15} \mathrm{Cl}_{2} \mathrm{NO}_{3}$ : C, 59.36; H, 4.15; N, 3.85. Found: C, 59.39; H, 4.40; N 3.87 .

7a. $(2.42 \mathrm{~g}, 41 \%)$; mp $85-87{ }^{\circ} \mathrm{C} ;{ }^{1} \mathrm{H}$ NMR $\delta 1.00\left(3 \mathrm{H}, \mathrm{t}, J=7 \mathrm{~Hz}, \mathrm{CH}_{3}-\mathrm{CH}_{2}\right), 4.08(2 \mathrm{H}, \mathrm{m}$, $\left.\mathrm{CH}_{3}-\mathrm{CH}_{2}-\right), 4.57(1 \mathrm{H}, \mathrm{d}, J=9 \mathrm{~Hz}, \mathrm{C} 4-\mathrm{H}), 6.24(1 \mathrm{H}, \mathrm{d}, J=9 \mathrm{~Hz}, \mathrm{C} 5-\mathrm{H}), 7.29-7.49$ (8H, m, ArH); MS m/z: 367, 365, $363\left(\mathrm{M}^{+}, 2 \%, 8 \%, 12 \%\right), 192$ (100), 148, 146 (11, 37). Anal. Calcd for $\mathrm{C}_{18} \mathrm{H}_{15} \mathrm{Cl}_{2} \mathrm{NO}_{3}$ : C, 59.36; H, 4.15; N, 3.85. Found: C, 59.59; H, 4.20; N, 3.98. The structure was confirmed by X-ray crystallographic analysis ${ }^{7}$.

trans-4,5-Dihydro-4-phenyl-3-(2,4,6-trimethylphenyl)-5-isoxazolecarboxylic acid ethyl ester 6b and trans-4,5-dihydro-5-phenyl-3-(2,4,6-trimethylphenyl)-4-isoxazolecarboxylic acid ethyl ester (7b). Reaction of $3 \mathbf{b}(6.00 \mathrm{~g}, 30.3 \mathrm{mmol})$ afforded a mixture of the title compounds $\mathbf{6 b}$ and $\mathbf{7 b}$ in the ratio 50:50.

6b. (2.99 g, 29\%); mp 83-85 ${ }^{\circ} \mathrm{C}$; ${ }^{1} \mathrm{H}$ NMR $\delta 1.35\left(3 \mathrm{H}, \mathrm{t}, J=7 \mathrm{~Hz}, \mathrm{CH}_{3}-\mathrm{CH}_{2}-\right), 1.98$ (3H, s, Ar$\left.\mathrm{CH}_{3}\right), 2.25\left[6 \mathrm{H}, \mathrm{s}, \mathrm{Ar}-\left(\mathrm{CH}_{3}\right)_{2}\right], 4.33\left(2 \mathrm{H}, \mathrm{q}, J=7 \mathrm{~Hz}, \mathrm{CH}_{3}-\mathrm{CH}_{2}-\right), 4.82(1 \mathrm{H}, \mathrm{d}, J=4 \mathrm{~Hz}, \mathrm{C} 5-\mathrm{H})$, $5.33(1 \mathrm{H}, \mathrm{d}, J=4 \mathrm{~Hz}, \mathrm{C} 4-\mathrm{H}), 7.14-7.28$ (7H, m, Ar-H); MS m/z: $337\left(\mathrm{M}^{+}, 7 \%\right), 264\left(\mathrm{M}^{+}-\right.$ $\left.\mathrm{CO}_{2} \mathrm{CH}_{2} \mathrm{CH}_{3}, 100\right), 161$ (70). Anal. Calcd for $\mathrm{C}_{21} \mathrm{H}_{23} \mathrm{NO}_{3}$ : C, 74.75; H, 6.87; N, 4.15. Found: C, 74.35; H, 6.66; N, 3.74 .

7b. (5.02 g, 49\%); mp 85-87 ${ }^{\circ} \mathrm{C} ;{ }^{1} \mathrm{H} \mathrm{NMR} \delta 0.93\left(3 \mathrm{H}, \mathrm{t}, J=7 \mathrm{~Hz}, \mathrm{CH}_{3}-\mathrm{CH}_{2}-\right), 2.22[6 \mathrm{H}, \mathrm{s}, \mathrm{Ar}-$ $\left.(\mathrm{CH} 3)_{2}\right], 2.28\left(3 \mathrm{H}, \mathrm{s}, \mathrm{Ar}-\mathrm{CH}_{3}\right), 4.00\left(2 \mathrm{H}, \mathrm{m}, \mathrm{CH}_{3}-\mathrm{CH}_{2}-\right), 4.37(1 \mathrm{H}, \mathrm{d}, J=9.5 \mathrm{~Hz}, \mathrm{C} 4-\mathrm{H}), 6.11$ $(1 \mathrm{H}, \mathrm{d}, J=9.5 \mathrm{~Hz}, \mathrm{C5}-\mathrm{H}), 7.36-7.47$ (7H, m, Ar-H); MS m/z: 337 (M+1 100\%), 192 (58), 186 (67), 104 (96). Anal. Calcd for $\mathrm{C}_{21} \mathrm{H}_{23} \mathrm{NO}_{3}$ : C, 74.75; H, 6.87; N, 4.15. Found: C, 74.88; H, 6.90; $\mathrm{N}, 4.08$.

trans-3-(4-tert-Butylphenyl)-4,5-dihydro-4-phenyl-5-isoxazolecarboxylic acid ethyl ester 6c and trans-3-(4-tert-butylphenyl)-4,5-dihydro-5-phenyl-4-isoxazolecarboxylic acid ethyl ester 7c. Reaction of $3 \mathbf{c}(1.00 \mathrm{~g}, 4.7 \mathrm{mmol})$ afforded a mixture of the title compounds $6 \mathbf{c}$ and $7 \mathbf{c}$ in the ratio $27: 73$.

6c. $(0.18 \mathrm{~g}, 11 \%)$; mp $94-96{ }^{\circ} \mathrm{C} ;{ }^{1} \mathrm{H}$ NMR $\delta 1.26\left[9 \mathrm{H}, \mathrm{s}, \mathrm{Ar}-\left(\mathrm{CH}_{3}\right)_{3}\right] 1.30\left(3 \mathrm{H}, \mathrm{t}, J=7 \mathrm{~Hz}, \mathrm{CH}_{3}-\right.$ $\left.\mathrm{CH}_{2}-\right), 4.27\left(2 \mathrm{H}, \mathrm{q}, J=7 \mathrm{~Hz}, \mathrm{CH}_{3}-\mathrm{CH}_{2}-\right), 4.93(1 \mathrm{H}, \mathrm{d}, J=4 \mathrm{~Hz}, \mathrm{C} 5-\mathrm{H}), 5.01(1 \mathrm{H}, \mathrm{d}, J=4 \mathrm{~Hz}$, 
C4-H), 7.26-7.35 (7H, m, Ar-H), 7.56 (2H, d, J=8.5 Hz, Ar-H); MS m/z: $351\left(\mathrm{M}^{+}, 32 \%\right), 278$ (100), 114 (30), 91 (44). Anal. Calcd for $\mathrm{C}_{22} \mathrm{H}_{25} \mathrm{NO}_{3}$ : C, 75.19; H, 7.17; N, 3.99. Found: C, $75.41 ; \mathrm{H}, 6.92 ; \mathrm{N}, 3.97$.

7c $(0.78 \mathrm{~g}, 47 \%)$; mp $77-79{ }^{\circ} \mathrm{C} ;{ }^{1} \mathrm{H}$ NMR $\delta 1.24\left(3 \mathrm{H}, \mathrm{t}, J=7 \mathrm{~Hz}, \mathrm{CH}_{3}-\mathrm{CH}_{2}-\right), 1.32$ [9H, s, Ar$\left.\left(\mathrm{CH}_{3}\right)_{3}\right], 4.24\left(2 \mathrm{H}, \mathrm{q}, J=7 \mathrm{~Hz}, \mathrm{CH}_{3}-\mathrm{CH}_{2}-\right), 4.42(1 \mathrm{H}, \mathrm{d}, J=6 \mathrm{~Hz}, \mathrm{C} 4-\mathrm{H}), 5.96(1 \mathrm{H}, \mathrm{d}, J=6 \mathrm{~Hz}$, C5-H), 7.35-7.39 (7H, m, Ar-H), 7.67 (2H, d, J=8.5 Hz, Ar-H); MS m/z: $351\left(\mathrm{M}^{+}, 46 \%\right), 336$ $\left(\mathrm{M}^{+}-\mathrm{CH}_{3}, 39\right), 192$ (48), 160 (36), 146 (58), 105 (100), 77 (43). Anal. Calcd for $\mathrm{C}_{22} \mathrm{H}_{25} \mathrm{NO}_{3}$ : C, 75.19; H, 7.17; N, 3.99. Found: C, 75.28; H, 7.45; N, 3.85.

trans-3-tert-Butyl-4,5-dihydro-4-phenyl-5-isoxazolecarboxylic acid ethyl ester 6d and trans3-tert-butyl-4,5-dihydro-5-phenyl-4-isoxazolecarboxylic acid ethyl ester 7d. Reaction of $3 \mathrm{~d}$ $(0.88 \mathrm{~g}, 6.49 \mathrm{mmol})$ afforded a mixture of the title compounds $\mathbf{6 d}$ and $7 \mathbf{d}$ in the ratio 26:74.

6d (0.15 g, 8\%); viscous yellow oil; ${ }^{1} \mathrm{H}$ NMR $\delta 1.06$ [9H, s, $\left.\left(\mathrm{CH}_{3}\right)_{3}-\right], 1.25\left(3 \mathrm{H}, \mathrm{t}, J=7 \mathrm{~Hz}, \mathrm{CH}_{3}\right.$ $\left.\mathrm{CH}_{2}-\right), 4.27\left(2 \mathrm{H}, \mathrm{q}, J=7 \mathrm{~Hz}, \mathrm{CH}_{3}-\mathrm{CH}_{2-}\right), 4.55(1 \mathrm{H}, \mathrm{d}, J=3 \mathrm{~Hz}, \mathrm{C} 5-\mathrm{H}), 4.77(1 \mathrm{H}, \mathrm{d}, J=3 \mathrm{~Hz}$, C4-H), 7.26-7.39 (5H, m, Ar-H); MS m/z: $202\left(\mathrm{M}^{+}-\mathrm{CO}_{2} \mathrm{CH}_{2} \mathrm{CH}_{3}, 25 \%\right), 57$ [( $\left.\mathrm{CH}_{3}\right)_{3}$, 100]. Anal. Calcd for $\mathrm{C}_{16} \mathrm{H}_{21} \mathrm{NO}_{3}$ : C, 69.79; H, 7.69; N, 5.09. Found: C, 69.70; H, 7.61; N, 4.85.

7d (0.64 g, 36\%); mp 45-46 ${ }^{\circ} \mathrm{C} ;{ }^{1} \mathrm{H}$ NMR $\delta 1.24$ [9H, s, $\left.\left(\mathrm{CH}_{3}\right)_{3}\right] 1.33\left(3 \mathrm{H}, \mathrm{t}, J=7 \mathrm{~Hz}, \mathrm{CH}_{3}-\mathrm{CH}_{2}-\right.$ ), $3.99(1 \mathrm{H}, \mathrm{d}, J=6.5 \mathrm{~Hz}, \mathrm{C} 5-\mathrm{H}), 4.29(2 \mathrm{H}, \mathrm{q}, J=7 \mathrm{~Hz}, \mathrm{CH} 3-\mathrm{CH} 2-), 5.76(1 \mathrm{H}, \mathrm{d}, J=6.5 \mathrm{~Hz}$, C4-H), 7.28-7.41 (5H, m, Ar-H); MS m/z: 202 (M+CO2CH2CH3, 15\%), 192 (68), 146 (44), 105 (100), 57 [(CH3)3, 74]. Anal. Calcd for C16H21NO3: C, 69.79; H, 7.69; N, 5.09. Found: C, 69.66; H, 7.72; N, 5.01 .

\section{General extraction procedure}

A solution of an approximately equimolar mixture of a regioisomeric pair of the isoxazolines 6ad $(0.5 \mathrm{mmol})$ and $7 \mathbf{a}-\mathbf{d}(0.5 \mathrm{mmol})$ in ethanol/water $(1: 4, \mathrm{v} / \mathrm{v}, 100 \mathrm{~mL})$ containing $\beta$-cyclodextrin $(5 \mathrm{mmol})$ was shaken vigorously with chloroform $(100 \mathrm{~mL})$ for $5 \mathrm{~s}$, then the organic layer was separated, dried $\left(\mathrm{MgSO}_{4}\right)$ and concentrated under reduced pressure. The residue was weighed and analysed using ${ }^{1} \mathrm{H}$ NMR spectroscopy. The results are shown in Table 1.

\section{Determination of the solubility of the isoxazolines 6a-d and 7a-d}

A solution of an approximately equimolar mixture of a regioisomeric pair of the isoxazolines 6ad $(0.5 \mathrm{mmol})$ and $7 \mathbf{a}-\mathbf{d}(0.5 \mathrm{mmol})$ in ethanol $(12.5 \mathrm{~mL})$ was added dropwise and with vigorous stirring to a mixture of ethanol $(12.5 \mathrm{~mL})$ and water $(75 \mathrm{~mL})$, equilibrated at $30{ }^{\circ} \mathrm{C}$. The resultant suspension was left to stand at $30{ }^{\circ} \mathrm{C}$ for $24 \mathrm{~h}$, then it was filtered twice through $0.2 \mu \mathrm{m}$ syringe filters (Sartorius Ministart ${ }^{\circledR}$ ) and once through a $0.02 \mu \mathrm{m}$ syringe filter (Whatman Anotop 25 Plus $\left.^{\circledR}\right)$. The filtrate was extracted with chloroform $(3 \times 50 \mathrm{~mL})$ and the combined extracts were dried $\left(\mathrm{MgSO}_{4}\right)$ and concentrated under reduced pressure. The residue was dissolved in acetonitrile $(50 \mu \mathrm{L})$ and analysed by HPLC [Waters Symmetry ${ }^{\circledR} \mathrm{C} 183.5 \mu \mathrm{m}(75 \mathrm{~mm} \times 4.6 \mathrm{~mm})$ column, eluting with acetonitrile/water $(7: 3, \mathrm{v} / \mathrm{v})]$, using one of the other isoxazolines $\mathbf{6 a - d}$ and 7a-d as a standard. A similar procedure was used to determine solubility in the presence of $\beta$ cyclodextrin $(5 \mathrm{mmol})$, which was added to the aqueous ethanol before adding the solution of the 
isoxazolines $\mathbf{6 a}-\mathbf{d}(1.0 \mathrm{mmol})$ and $7 \mathbf{a}-\mathbf{d}(1.0 \mathrm{mmol})$ in ethanol. However, in these experiments the filtrates were analysed directly by HPLC, without extraction into chloroform. The results are shown in Table 2.

\section{Acknowledgements}

The authors gratefully acknowledge the financial support provided for this work by CSIRO Molecular Science, and the award of an Australian Postgraduate Award (Industry) to G.J.V .

\section{References and Notes}

1. (a) Rama Rao, K.; Bhanumathi, N.; Srinivasan, T. N.; Sattur, P. B. Tetrahedron Lett. 1990, 31, 899. (b) Rama Rao, K. Pure Appl. Chem. 1992, 64, 1141. (c) Rama Rao, K.; Bhanumathi, N.; Sattur, P. B. Tetrahedron Lett. 1990, 31, 3201. (d) Rama Rao, K.; Nageswar, Y. V. D.; Bhanumathi, N.; Srinivasan, T. N. Indian J. Chem. 1994, 33B, 171. (e) Rama Rao, K.; Nageswar, Y. V. D.; Sampathkumar, H. M. J. Chem. Soc., Perkin Trans. 1 1990, 3199.

2. Easton, C. J.; Hughes, C. M. M.; Tiekink, E. R. T.; Savage, G. P.; Simpson, G. W. Tetrahedron Lett. 1995, 36, 629.

3. Matsui, Y.; Nishioka, T.; Fujita, T. Top. Curr. Chem. 1985, 128, 61.

4. Easton, C. J.; Lincoln, S. F. Modified Cyclodextrins: Scaffolds and Templates for Supramolecular Chemistry; Imperial College Press: London, 1999.

5. Easton, C. J.; Hughes, C. M. M.; Savage, G. P.; Simpson, G. W. Adv. Heterocycl. Chem. 1994, 60, 261.

6. (a) Christl, M.; Huisgen, R.; Sustmann, R. Chem. Ber. 1973, 106, 3275. (b) Christl, M.; Huisgen, R. Tetrahedron Lett. 1968, 50, 5209.

7. Easton, C. J.; Hughes, C. M. M.; Tiekink, E. R. T.; Savage, G. P.; Simpson, G. W. Z. Kristallogr. 1995, 210, 699.

8. Lui, K.-C.; Shelton, B. R.; Howe, R. K. J. Org. Chem. 1980, 45, 3916. 